\title{
Effect of Satisfaction with Conventional Housing on Willingness to Pay for Green Buildings in Makurdi
}

\author{
Vincent Kpamsar Takuh ${ }^{1}$, Fidelis Awa Abang ${ }^{1}$, Saheed Olayinka Akinyemi ${ }^{1}$
}

${ }^{1}$ Abubakar Tafawa Balewa University

Tafawa Balewa Way, P. M. B. 0248, Bauchi, 740272, Nigeria

DOl: $10.22178 /$ pos. $77-4$

JEL Classification: 018

Received 20.11.2021

Accepted 28.12.2021

Published online 31.12.2021

Corresponding Author:

Vincent Kpamsar Takuh

kpamvincent@gmail.com

(c) 2021 The Authors. This article

is licensed under a Creative

Commons Attribution 4.0

License@ @ (1)

\begin{abstract}
Examining willingness to pay for the green residential building has become necessary since modern technology in the built environment drives towards providing green buildings to reduce the adverse effect of the building sector on Mother Earth. Yet, it is worrisome that the building industry in Nigeria is struggling to meet housing needs with conventional buildings. Hence, this paper aimed to investigate the effect satisfaction with traditional housing has on willingness to pay for green buildings to aid green building investment decisions in Makurdi. Three objectives pursued aim. The survey research strategy adopted using questionnaires as a research instrument as suitable for contingent valuation surveys. Three hundred samples were taken from a sample frame of 552 using the stratified sampling technique. Data collected were analysed using weighted mean, binary logistic model, and linear regression. The findings revealed that Makurdi householders are satisfied with conventional housing yet are willing to pay a $3.3 \%$ premium price to purchase green buildings; satisfaction with traditional housing negatively affects willingness to pay for green buildings. However, such an effect is not significant. Recommendations are made to create awareness on the importance of building green while investors are advised to invest in green homes.
\end{abstract}

Keywords: satisfaction; conventional housing; green building; willingness to pay; contingent valuation.

\section{INTRODUCTION}

Housing remains a relevant asset to man, not just limited to shelter against harsh weather. But equally stimulates growth and ensures the sustainability of inhabitants in the ecosystem; housing equally plays a vital role in determining economic prosperity and wellbeing for both residents and the communities in which they live. For instance, in Ghana, housing contributes about $30 \%$ of the country's GDP [20], while the real estate sector accounts for $5.63 \%$ of the Nigerian economy in GDP [5]. As a result of man and housing being inseparable, humans tend to satisfy the ever-growing housing need. Over the last few decades, conventional housing has negatively impacted the environment by extension [11].

The author [9] reported that globally the building industry accounts for up to $30 \%$ of carbon emissions. Also, the building industry is said to have tapped at about $50 \%$ of material resources from nature, $50 \%$ of waste production is generated from the building sector, $40 \%$ of global energy consumption is building-related, and $50 \%$ of greenhouse emission is as a result of building [6]. Yet it is regrettable to know that in all of the harm the building industry has done to Mother Earth, most developing countries such as Nigeria, with a current housing deficit of about 22 million units [1], are yet to meet the basic conventional housing needs of her citizens [13].

Recognising, therefore, that as humans constantly seek development in all areas of life, including but not limited to the building sector, which is continuously in the quest to meet man's second most important need (housing), sustainability should be attained while meeting these needs through development [11]. Hence the world is moving closer to a global agenda anchored by Sustainable Development Goals (SDGs) initiatives and has given rise to the notion of green buildings, which has become a new trend in the innovative technology field of the built environment. Many developed and a few developing countries 
have established goals and methods to prioritise planning and action to seize green building opportunities [10]. Through various phases of development; design, construction, operation, maintenance, and destruction, green buildings are designed to limit their influence on climate change and save natural resources [3]. Green buildings offer to save energy, protect the environment, use building materials sourced locally, and maintain social equity among occupants. Green buildings have piqued the curiosity of developers, designers, financiers, and building owners in recent years by providing efficient service, improved quality of life, and improved livability for future generations [10].

The benefits of green homes cannot be overemphasised as identified to include; aesthetic, improving wellbeing of occupants, greater return on capital, last long, less maintenance cost, and returns entirely to the earth when abandoned [9, 8]. However, the cost implication of building green has been an issue of debate as researchers such as [8] opined that an ideal green building is not expensive to produce. In contrast, [18] and [17] argued that building green has additional cost implications. The researchers of this paper share that such buildings may be cost demanding to acquire but cheaper than their conventional counterparts when comparing the cost in use. Despite how promising building green seems and the widespread adoption by developed states of the world, it is worrisome that Nigeria and most developing forms of the world are yet to embrace the concept of building green [16]. Even worse, Nigeria is yet to meet conventional housing needs for its citizens [13].

It is, therefore, crucial to examine if householders' will be willing to pay for green residential buildings in an attempt to guide investment decisions while trying to breach the housing deficit. Notwithstanding, it is essential to consider the targeted market behaviour to introduce the new product (green building) to the Makurdi property market. Hence [4] exposed two views of different authors regarding the satisfaction-loyalty relationship, the first view position that satisfaction positively affects loyalty. That means that if householders are satisfied with current conventional housing, they will be contented with their homes, less likely to switch to green options and may not be willing to pay a premium to purchase green buildings. Studies also reveal that resident satisfaction or dissatisfaction with their housing influences their intentions to stay or leave [7].
The second view asserts that pleasure does not necessarily translate to loyalty even though loyal consumers are usually satisfied [4]. That is to say, satisfaction with conventional housing will not hinder demand for another product such as green buildings.

It is on the premises of the preceding that this study is hinged to assess if satisfaction with conventional housing will hinder willingness to pay for green building or not. Various studies have been conducted on willingness to pay for green buildings, such as [18] and [21]. Also, multiple studies have been undertaken on residential housing satisfaction, such as [20] and [7]; however, there is limited literature on willingness to pay for green building features in Nigeria. Only [16] researched this area in Nigeria but focused on willingness to pay for green building features in Lagos prime residential submarket. Hence the knowledge gap, as no research has been done on the effect of satisfaction with conventional housing on willingness to pay for green buildings, which this paper attempted to fill.

The paper aimed to investigate the effect satisfaction with conventional buildings has on willingness to pay for green residential buildings to aid green building investment decisions in Makurdi. Three objectives were pursued in an attempt to achieve the aim.

1. To determine the level of householders satisfaction with conventional housing attributes in Makurdi.

2. To estimate the amount householders will pay for a green residential building in Makurdi.

3. To assess the effect of householders' satisfaction with conventional housing on the amount householders will pay for a green residential building in Makurdi.

\section{METHODOLOGY}

The quantitative research approach was employed for this study, under which the descriptive research design is adopted based on the nature of the investigation. This study was designed as a cross-sectional study. The study took a crosssection of the population at one-shot contact with the respondents to obtain data for analysis. In addition, this study was designed as a prospective study based on a reference period. The aim is to forecast the price to be paid for a good yet to 
be provided. And how the consumers in the forecasted market will act.

Survey research strategy is employed due to its wide acceptance in contingent valuation studies $[16,18]$ since the study focus on estimating willingness to pay for a none market good (green building in Makurdi context) by creating a hypothetical market and asking respondents to state their maximum willingness to pay for a 3bedroom green residential building close to Makurdi international Market. The instrument used for data collection was a structured questionnaire consisting of sections that demanded information 1) on the demographic data of the respondents; 2) respondents' satisfaction with conventional housing attributes; 3) the contingent valuation survey section, which combined the payment card approach to contingent valuation survey with open-ended question method of contingent valuation survey.

Six housing estates within Makurdi, as limited by the scope of this paper, were selected for the survey, namely; BIPC Housing Estate Nyiman, BIPC Ever Green Housing Estate North Bank, Aper Aku Housing Estate, Eskay Housing Estate Naka Road, Eskay Housing Estate Akpehe and Grace land Housing Estate. Householders of the estate mentioned earlier constituted the population for the study. This amounted to a sample frame of 552 householders. A sample size of 300 householders was drawn from the sample frame using the table of Krejcie and Morgan, which adjustment was made to take care of uncertainty of householders not returning questionnaires, damage of questionnaires, missing data and outliers' exclusion. The study employed the stratified sampling technique where each of the six housing estates surveyed formed a stratum.

The survey data was retrieved, but as it is familiar with surveys, about 26 questionnaires were not returned, representing approximately 8.7\% of the total questionnaires distributed, resulting in 274 retrieved questionnaires. Descriptive statistic (weighted mean) was further used to answer the first research objective to assess householders' satisfaction with conventional housing attributes. A six-point Likert scale was used to measure happiness, in which the decision rule is presented in Table 1.
Table 1 - Decision Making Bench Mark (Likert Scale) [19]

\begin{tabular}{|l|l|l|}
\hline Points & Decision & Bench Mark \\
\hline 1 & Extremely Dissatisfied & $1.00-1.49$ \\
\hline 2 & Very Dissatisfied & $1.50-2.49$ \\
\hline 3 & Dissatisfied & $2.50-3.49$ \\
\hline 4 & Satisfied & $3.50-4.49$ \\
\hline 5 & Very Satisfied & $4.50-5.49$ \\
\hline 6 & Extremely Satisfied & $5.50-6.00$ \\
\hline
\end{tabular}

The second objective, which involved estimating the value householders' are willing to pay for a 3bedroom green building, was analysed using a binary logistic. The logistic model explains the willingness to pay (WTP) as a function of observable characteristics of the respondents [2]. From the binary logistic output, the Mean Willingness to Pay (MWTP) was then computed using the formula below:

$$
\text { MWTP }=\frac{-\alpha}{\beta 1},
$$

where $\alpha=$ Intercept and $\beta_{1}=$ Coefficient of Bid Value

The third objective, which assessed the effect of householders' satisfaction with conventional housing on the amount householders will pay for a green residential building, was analysed using linear regression.

\section{RESULTS AND DISCUSSION}

Makurdi Householders' Level of Satisfaction with Conventional Housing Attributes. This study adopted the weighted mean to measure Makurdi householders' level of satisfaction with conventional housing attributes. The decision-making benchmark provided earlier was used as the satisfaction index to explain their level of satisfaction. Table 2 shows the general satisfaction level with their conventional housing attributes.

Regarding the residential satisfaction index provided earlier, Table 2 shows that Makurdi householders are generally satisfied with the property attributes of their conventional housing, having a mean of 3.75, which is within the range of confidence on the decision benchmark (3.50-4.49). 
Table 2 - Level of Satisfaction with Conventional Housing Attributes

\begin{tabular}{|c|c|c|c|c|c|}
\hline & $\mathrm{N}$ & Minimum & Maximum & Mean & Rank \\
\hline Infrastructural facilities & 274 & 1 & 6 & 3.20 & III \\
\hline Access to work Place & 274 & 1 & 6 & 3.36 & II \\
\hline Proximity to Urban Development & 274 & 1 & 6 & 3.38 & $\mathrm{I}$ \\
\hline NEIGHBOURHOOD ATTRIBUTES & 274 & 1.00 & 6.00 & 3.3127 & 3 \\
\hline Sounds Control & 274 & 1 & 6 & 3.65 & II \\
\hline Erosion Control & 272 & 1 & 6 & 3.35 & III \\
\hline Natural Environment & 274 & 1 & 6 & 3.96 & I \\
\hline ENVIRONMENTAL ATTRIBUTES & 274 & 1.00 & 6.00 & 3.6533 & 2 \\
\hline Construction Materials & 272 & 1 & 6 & 3.41 & $\mathrm{~V}$ \\
\hline Finishing & 274 & 1 & 6 & 3.29 & IV \\
\hline Number of Rooms & 274 & 1 & 6 & 3.96 & II \\
\hline Size of Rooms & 271 & 1 & 6 & 3.92 & III \\
\hline Window Design & 273 & 1 & 6 & 4.18 & I \\
\hline PROPERTY ATTRIBUTE & 274 & 1.00 & 6.00 & 3.7502 & 1 \\
\hline Toilet Facilities & 273 & 1 & 6 & 3.77 & I \\
\hline Power Supply & 274 & 1 & 6 & 3.53 & II \\
\hline Waste Deposal System & 274 & 1 & 6 & 2.72 & IV \\
\hline Building Water Supply & 274 & 1 & 6 & 2.86 & III \\
\hline DWELLING FACILITIES & 274 & 1.00 & 6.00 & 3.2202 & 4 \\
\hline TOTAL SATISFACTION & 274 & 1.60 & 5.73 & 3.5025 & \\
\hline Valid N (listwise) & 266 & & & & \\
\hline
\end{tabular}

Similarly, regarding satisfaction with environmental attributes, the mean value of 3.65 implies that Makurdi householders are generally satisfied with the ecological characteristics of their conventional housing since the mean lies between 3.50 and 4.49 .

In addition, Table 2 reveals that householders were dissatisfied with all the items used to measure neighbourhood attributes. Their mean values ranged between the disappointing range of the decision benchmark (2.50-3.49). By implication, the mean value of satisfaction with neighbourhood attributes (3.31) falls within the same degree of dissatisfaction, which positions that Makurdi householders are generally dissatisfied with the neighbourhood attribute of their conventional housing. Regarding satisfaction with dwelling facilities, householders reviewed general discontent, with a mean value of 3.22.

Taking a critical look at the results in Table 2, Makurdi householders are satisfied with two of the housing attributes studied (Property Attributes and Environmental Attributes, in order of priority) and dissatisfied with neighbourhood attributes and dwelling facilities (in order of preference). By generalisation, it can be said that householders are satisfied with their conventional housing attribute as a total mean value of 3.50 can be seen in Table 2. This finding corresponds with [12], who opined that building fea- tures and housing quality are strongly related to residential satisfaction. Also similar to the study of [14], which considered middle-income households in Malaysia. Householders in this study and that of [14] have shown that they are all not satisfied with the property attributes and environmental attributes.

Estimated Amount Medium Income Earners will Pay for Three Bedroom Green Residential Bungalow. The ODDS used for computation in the logistic model were based on the minimum price $(\mathrm{N} 15,750,000)$ forecasted with the aid of literature through premium prices and professional advice, which was further adopted as the minimum likelihood price of a green building, where any value below the forecasted cost was recorded as 0 and that of the indicated price and above as 1 . Table 3 , therefore, reports the output of the logistic model.

Table 3 presents an a $\beta 1$ coefficient of 0.00004549 and intercept $(\alpha)$ of -700.877 , which is further employed to estimate the mean willingness to pay for a three-bedroom green residential bungalow close to the international market Makurdi. The result of the computed MWTP reveals that Makurdi householders are willing to pay $\mathrm{N} 15,407,276.32$ (Say; 15,500,000) to purchase a three-bedroom green residential bungalow. 
Table 3 - Parameter Estimates from Logistic Model

\begin{tabular}{|l|c|c|c|c|c|c|c|}
\hline \multirow{2}{*}{ Parameter } & \multirow{2}{*}{$\beta$} & \multirow{2}{*}{ Std. Error } & \multicolumn{2}{|c|}{ 95\% Wald Confidence Interval } & \multicolumn{3}{|c|}{ Hypothesis Test } \\
\cline { 4 - 8 } (Intercept) & -700.877 & 41582.3907 & -82200.865 & 80799.111 & .000 & 1 & .987 \\
\hline Age & .597 & 1399.6151 & -2742.598 & 2743.792 & .000 & 1 & 1.000 \\
\hline Persons & .416 & 1124.5707 & -2203.702 & 2204.535 & .000 & 1 & 1.000 \\
\hline Education & -.053 & 1678.8171 & -3290.474 & 3290.368 & .000 & 1 & 1.000 \\
\hline Income & -.724 & 1303.5567 & -2555.648 & 2554.200 & .000 & 1 & 1.000 \\
\hline Bid & $4.549 \mathrm{E}-5$ & .0026 & -.005 & .005 & .000 & 1 & .986 \\
\hline (Scale) & $1 \mathrm{a}$ & & & & & & \\
\hline
\end{tabular}

Notes: Dependent Variable: Desire. Model: (Intercept), Age, Persons, Education, Income, Bid

Considering the cost of buying a newly completed standard three-bedroom conventional residential house in Makurdi, the result reveals that Makurdi householders are willing to pay a 3.3\% premium for green features. This finding relates with that of [15], who in their study showed that commercial and industrial building users of Ibadan were willing to pay between $1 \%$ and $10 \%$ as premium price.

Effect of Householders' Satisfaction with Conventional Housing on the Amount Householders Will
Pay for a Green Residential Building in Makurdi. This study measured if satisfaction or dissatisfaction with current conventional housing affects Makurdi householders' willingness to pay for a green building and the pattern of such effect. A linear regression model was developed, which considered the general satisfaction of all conventional housing attributes as the predictors while the amount each householder is willing to pay as the dependent variable.

Table 4 - Model Summary

\begin{tabular}{|l|l|l|l|l|}
\hline Model & R & R Square & Adjusted R Square & Std. Error of the Estimate \\
\hline 1 & $.068 \mathrm{a}$ & .005 & .001 & 3514277.071 \\
\hline
\end{tabular}

Notes: a) Predictors: (Constant), satisfaction

Table 4 shows $\mathrm{R}$ with the value of 0.068 , indicating a $6.8 \%$ relationship between the predictor (Satisfaction with conventional housing) and the dependent variable (amount willing to pay). $\mathrm{R}$ Square in the model goes to tell that satisfaction with traditional accommodation (independent variables) accounts for only $0.5 \%$ variance in the amount willing to pay (dependent variable); in other words, the independent variables have only $0.5 \%$ effect on the dependent variable. This means that $99.5 \%$ of the variance is accounted for by other factors not considered in this model.

Table 5 - Coefficients

\begin{tabular}{|c|l|c|c|c|c|c|}
\hline \multicolumn{2}{|c|}{ Model } & \multicolumn{2}{c|}{ Unstandardised Coefficients } & Standardised Coefficients & & \multirow{2}{*}{ Sig. } \\
\cline { 2 - 7 } & \multicolumn{1}{|c|}{ B } & Std. Error & Beta & & 17.039 & .000 \\
\hline \multirow{2}{*}{1} & (Constant) & 17228089.181 & 1011098.160 & -.068 & -1.077 & .283 \\
\cline { 2 - 8 } & Satisfaction & -303836.814 & 282204.555 & &
\end{tabular}

Notes: a) Dependent Variable: Amount Willing to Pay

Table 5 further reports the contribution of the predictor variable to the change of the dependent variable with all other factors held constant. The Unstandardised $\beta$ Coefficients in Table 5 reveal that; for a unit increase in satisfaction with con- ventional housing, there will be N303,837 decrease in the amount willing to pay, which this variation is not significant as seen in the reported $\mathrm{p}$-value of 0.283 , which is greater than 0.05 . The worth of note is that the effect of satisfaction with 
conventional housing on the amount willing to pay is negative. That is to say, as one is satisfied with traditional accommodation, they will pay less for green buildings. However, this effect is not significant. The relationship between the dependent and independent variables seems weak, and the independent variable's contribution to the dependent variable is meagre. This finding justifies the view of researchers who believe that satisfaction does not necessarily translate to loyalty [4].

\section{CONCLUSIONS AND RECOMMENDATIONS}

This paper concludes that Makurdi householders are satisfied with their conventional housing attributes. Yet, they are willing to pay a $3.3 \%$ premium to purchase green residential buildings. Their satisfaction with traditional housing will not restrain their willingness to pay and patronage for green residential buildings even though satisfaction with conventional housing is seen to hurt the amount willing to pay. Nevertheless, the premium price householders are eager to pay is relatively low considering the economic implication of building green in an economy such as $\mathrm{Ni}$ geria's. However, this low premium is a result of a lack of prior knowledge on the concept of build- ing green which the researchers believe that Makurdi householders are likely to pay higher premium prices to purchase green buildings. Therefore, real estate investors may consider delving into the production and supply of green buildings in the study area considering militating factors.

This paper further recommends that sensitisation and awareness creation be done regarding building green and, by extension, sustainable development. The government is urged to consider the media approach in creating awareness on the importance of building green and also organise seminars, workshops and public lectures in strategic locations with the help of professionals of the sustainable built environment. The government is encouraged to develop a green housing policy that will define and regulate the development of the building industry and establish a green building certification scheme of Nigeria that will provide a green rating label. Mortgage facilities should be made readily available at friendly interest rates to investors who are ready to build green to encourage the adoption of the concept of building green. Lastly, investors and the government are encouraged to invest in green homes while closing the housing deficit gap in Nigeria.

\section{REFERENCES}

1. Abdullahi, O. L. (2021). Social Welfare and Access to Housing Among the Middle and Low-income Earners in Nigeria: A Review of Frameworks for Housing Delivery. Public Policy and Administration Research. doi: 10.7176/ppar/11-1-08

2. Adamu, A., Yacob, M., Radam, A., \& Hashim, R. (2015). Factors Determining Visitors' Willingness to Pay for Conservation in Yankari Game Reserve, Bauchi, Nigeria. International Journal of Economics and Management, 9(5), 95-114.

3. Altomonte, S., Schiavon, S., Kent, M. G., \& Brager, G. (2017). Indoor environmental quality and occupant satisfaction in green-certified buildings. Building Research \& Information, 47(3), 255274. doi: 10.1080/09613218.2018.1383715

4. Curtis, T. (2009). Customer Satisfaction, Loyalty, and Repurchase: Meta-Analytical Review, and Theoretical and Empirical Evidence of Loyalty and Repurchase Differences (Doctoral dissertation). Retrieved from https://nsuworks.nova.edu/cgi/viewcontent.cgi?article=1022\&context=hsbe_etd

5. Chidi, U. (2017, May 16). The Nigeria Real Estate Market Review \& Strategic Outlook 2017. Retrieved from https://ubosieleh.com/the-nigeria-real-estate-market-review-strategic-outlook-2017

6. Hill, A., Han, Y., Taylor, J. E., Shealy, T., Pearce, A., \& Mohammadi, N. (2019). Empirical Examination of Pro-environmental Behaviors in Traditional, Green Featured, and LEED Certified Buildings. Energy Procedia, 158, 3982-3987. doi: 10.1016/j.egypro.2019.01.843 
7. Hur, M., \& Morrow-Jones, H. (2008). Factors that Influence Residents' Satisfaction with Neighborhoods. Journal of Environment and Behavior, 40, 619-635. doi: 10.1177/0013916507307483

8. Illankoon, I. M. C. S., Tam, V. W. Y., Le, K. N., \& Shen, L. (2017). Key credit criteria among international green building rating tools. Journal of Cleaner Production, 164, 209-220. doi: 10.1016/j.jclepro.2017.06.206

9. Jiang, H., \& Payne, S. (2019). Green housing transition in the Chinese housing market: A behavioural analysis of real estate enterprises. Journal of Cleaner Production, 241, 118381. doi: 10.1016/j.jclepro.2019.118381

10. Khan, J., Zakaria, R., Shamsudin, S., Abidin, N., Sahamir, S., Abbas, D., \& Aminudin, E. (2019). Evolution to Emergence of Green Buildings: A Review. Administrative Sciences, 9(1), 6. doi: 10.3390/admsci9010006

11. Klarin, T. (2018). The Concept of Sustainable Development: From its Beginning to the Contemporary Issues. Zagreb International Review of Economics and Business, 21(1), 67-94. doi: 10.2478/zireb-2018-0005

12. Mohit, M. A., \& Al-Khanbashi Raja, A. M. M. (2014). Residential satisfaction - concept, theories and empirical studies. Planning Malaysia Journal, 12(3). doi: 10.21837/pmjournal.v12.i3.131

13. Moore, E. A. (2019). Addressing Housing Deficit in Nigeria: Issues, Challenges and Prospects. Economic and Financial Review, 54(4), 15-31.

14. Oh, L. S. (2000). Housing Satisfaction of Middle-Income Household in Bandar Baru, Bangi, Selangor. (Dissertation).

15. Olaleye, A., Ayodele, T. O., \& Komolafe, M. O. (2015). The Relevance of Green Building Practice in Emerging Markets: A Perceptual Analysis of Commercial and Industrial Building Users in Ibadan, Nigeria. Journal of Sustainable Real Estate, 7(1), 41-59.

16. Otegbulu, A. C. (2018). Willingness to Pay for Sustainable Features in Prime Residential Submarkets of Lagos. Journal of Sustainable Real Estate, 10(1), 163-189. doi: 10.1080/10835547.2018.12091908

17. Oyedokun, T. B. (2017). Green premium as a driver of green-labelled commercial buildings in the developing countries: Lessons from the UK and US. International Journal of Sustainable Built Environment, 6(2), 723-733. doi: 10.1016/j.ijsbe.2017.12.007

18. Robinson, S., Simons, R., Lee, E., \& Kern, A. (2016). Demand for Green Buildings: Office Tenants' Stated Willingness-to-Pay for Green Features. Journal of Real Estate Research, 38(3), 423-452. doi: 10.1080/10835547.2016.12091450

19. Asún, R. A., Rdz-Navarro, K., \& Alvarado, J. M. (2015). Developing Multidimensional Likert Scales Using Item Factor Analysis. Sociological Methods \& Research, 45(1), 109-133. doi: 10.1177/0049124114566716

20. Salisu, U. O., Odulaja, A. O., Ogunseye, N. O., Fasina, S. O., \& Okunubi, S. A. (2019). Residents' Satisfaction with Public Housing in Lagos, Nigeria. Ghana Journal of Geography, 11(1), 180-200.

21. Yau, Y. (2012). Willingness to pay and preferences for green housing attributes in Hong Kong. Journal of Green Building, 7(2), 137-152. doi: 10.3992/jgb.7.2.137 